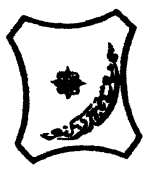

Bayero Journal of Pure and Applied Sciences, 11(1): 273 - 281

ISSN 2006 - 6996

\title{
ADSORPTION OF BROMOPHENOL BLUE AND BROMOTHYMOL BLUE DYES ONTO RAW MAIZE COB
}

\author{
Safiyya Ibrahim Abubakar and Muhammad B. Ibrahim \\ Department of Pure and Industrial Chemistry, Bayero University, P.M.B. 3011, Kano - Nigeria \\ *Correspondence author: safiyyaiaramadan@gmail.com; mbibrahim.chm@buk.edu.ng
}

\section{ABSTRACT}

The adsorption of Bromophenol blue (BPB), and Bromothymol blue (BTB) onto raw maize cob from aqueous solution was studied using bach adsorption technique, in which the influence of contact time, dosage, concentration, temperature, and $\mathrm{pH}$, were investigated as well as characterizing the adsorbent using Fourier Transform Infrared (FTIR) spectroscopy, surface morphology using scanning electron microscopy and $\mathrm{pH}$ of point of zero charge ( $\mathrm{pH}$ PZC). Results showed that Bromophenol blue and Bromothymol blue removal reaches optimum percentage about $96.53 \%$, and $94.39 \%$ with equilibrium time within 125 and 110 minutes respectively. For both dyes the removal efficiency was found to increase with increasing initial dye concentration from $10 \mathrm{mg} / \mathrm{l}$ to $100 \mathrm{mg} / \mathrm{l}$, and adsorption efficiency were found to be high at lower $\mathrm{pH}$. also, increase in the dosage of the adsorbent leads to increase in the adsorption process for BPB but shows decrease for BTB. The equilibrium adsorption data were analyzed using Langmuir, Freundlich, Temkin, and Dubinnin-Ruduskevich (D-R). The results revealed that the experimental data fits Temkin isotherm with $R^{2}$ values of 0.957 and 0.971 for BPB and BTB respectively. Kinetic analyses were conducted using pseudo-first, second-order models, elovich equation and the intra-particle diffusion model. The regression results in addition to $q_{e}$ experimental and $q_{e}$ calculated showed that the adsorption kinetics was more accurately represented by pseudo-second-order model. Values of activation parameters such as free energy changes $(\Delta G)$, enthalpy change $(\Delta H)$, and entropy change $(\Delta S)$ were calculated using vant Hoff equation. All $\Delta G$ values were negative indicating that the adsorption was feasible and spontaneous. The result indicated that raw maize cob can be used as adsorbent for the removal of the tested dyes.

Keywords: Adsorbate, Adsorbent, Adsorption, Maize cob, \% Removal

\section{INTRODUCTION}

Dyes are complex chemical substances that bear stable aromatic rings synthesized to impart strong and persistent colour that does not degrade on exposure to light (Ibrahim and Sani 2014). Dyes are generally applied in an aqueous solution, and may require a mordant to improve their fastness on fibres (Karasavvidis et al., 2013; Saritha et al., 2015). Direct skin contact of dyes has been reported to result in various types of health problems like hypersensitivity, mutagenic and carcinogenic effects, allergy and asthma, skin eczema and immunosuppressive effects (Banerjee and chattopadhyaya, 2013; Omran et al., 2016).. This leads to raise concern regarding its use as well as its removal from aqueous solutions. The dye impact toxicity and impedes light penetration and thus upsets the biological activity (Alwan et al., 2015; Sayan et al., 2014; Hassan and Mahdi, 2016). Several methods including physical, chemical and biological processes have been used for the removal of dyes from effluents. Chemical and biological methods are effective for decolourization, however, they require energy and special equipment; in addition, large amounts of byproducts are often generated (Ramesh et al., 2013; Kandisa et al., 2016). Physical methods such as adsorption, ion exchange, and membrane filtration were generally effective for decolourization without producing unwanted by products. Among treatment technologies, sorption process has received a lot of attention due to its simplicity, high efficiency, eco-friendly nature as well as the availability of a wide range of adsorbent with low cost, easy maintenance, no special operational skills and local availability (Suteu et al., 2011; Gayathiri et al., 2013; Zvzdova and Georgieva, 2013).

Maize cob is an example of plant residues that are mainly composed of lingocellulose materials. They have relatively large surface areas that can provide intrinsic adsorptive sites to many substrates and inherently adsorb waste chemicals such as dyes and cations in water due to columbic interaction and physical adsorption (Ibrahim and Jimoh 2011). 


\section{MATERIALS AND METHODS}

Adsorbents Preparation

The maize cob was obtained and washed with tap water followed by distilled water to remove surface impurities and dried in an oven at $105{ }^{\circ} \mathrm{C}$ for 2 hours. The dried maize cob (corn cob) was crushed using mortar and pestle and then pulverised using blender and sieved using 425 micrometer, the powder was kept in tightly closed container for application.

Batch Adsorption studies

Adsorption studies of Bromophenol blue, and Bromothymol blue dyes were performed. In each experiment $50 \mathrm{~cm}^{3}$ of dye solution in a 120 $\mathrm{cm}^{3}$ sample bottle of known concentration of desired time, temperature, dosage, and $\mathrm{pH}$. The bottle were agitated and the mixture was filtered and the filterate was then centrifuged for 5 minutes at $4000 \mathrm{rpm}$ and the clear supernatant was used to determined the final concentration of the dyes spectrophotometrically using UV-Visible spectrophotometer (model Hitach 2800) at a corresponding $\lambda_{\max }$ of $591.22 \mathrm{~nm}$ for Bromophenol blue (BPB) and $430.9 \mathrm{~nm}$ for Bromothymol blue (BTB). The percentage of dye adsorbed and the amount adsorbed were calculated as (Abechi et al., 2013).

$$
\% R=\frac{C_{O}-C e}{C_{O}} X 100
$$

Where $\mathrm{Co}_{0}$ is the initial concentration of the adsorbate $(\mathrm{mg} / \mathrm{L})$ and $\mathrm{Ce}$ is the equilibrium concentration (mg/L).

$q_{e}=\frac{\left(C_{O}-C_{e}\right) V}{W}$

Where $\mathrm{w}(\mathrm{g})$ is the weight of adsorbent and $\mathrm{V}$ $\left(\mathrm{cm}^{3}\right)$ is the volume of the adsorbate. The effects of various parameters on dye adsorption by raw maize cob were investigated such as adsorbent dosage (0.5-4.0 g), contact time (5 $135 \mathrm{~min})$, initial dye concentration (10 - 100 $\mathrm{mg} / \mathrm{L})$, temperature $\left(25-45{ }^{\circ} \mathrm{C}\right)$ and $\mathrm{pH}(2-12)$ (Bentahar et al., 2016).

\section{RESULTS AND DISCUSSION}

Characterization of the adsorbent

Fourier Transform- Infrared (FT-IR)

The FT-IR absorption peaks of raw maize cob (RW) before and after adsorption and the functional group assignment are given in Table 1. Values in parenthesis represent the change in the wavenumber $\left(\mathrm{cm}^{-1}\right)$ after the respective dye adsorption. The result demonstrates that after the adsorption shifting occurs both to higher and lower wave numbers, indicating that there were binding processes, taking place on the surface of adsorbents as equally observed by Nale et al. (2012) on the adsorption of $\mathrm{Pb}$ (II) and $\mathrm{Ni}$ (II) on activated maize cob.

Table 1: FT-IR results of raw maize cob before and after adsorption of dyes.

\begin{tabular}{|c|c|c|c|c|c|c|}
\hline \multirow{2}{*}{$\begin{array}{l}\text { Peak } \\
\text { s }\end{array}$} & \multicolumn{5}{|c|}{ Raw Maize cob $\bar{v}\left(\mathrm{~cm}^{-1}\right)$} & \multirow{2}{*}{$\begin{array}{l}\text { Functional } \\
\text { Group } \\
\text { Assignment }\end{array}$} \\
\hline & Before Adsorption & \multicolumn{4}{|c|}{ After Adsorption with } & \\
\hline 1 & 3287 & 3273 & $(-14)$ & 3286 & $(-1)$ & $\mathrm{N}-\mathrm{H}$ stretching \\
\hline 2 & 2922 & 2921 & $(-1)$ & 2922 & (0) & Bonded-OH \\
\hline 3 & 1023 & 997 & $(-26)$ & 1022 & $(-1)$ & C-N group \\
\hline 4 & 2129 & 2114 & $(-15)$ & 2114 & $(-15)$ & $C \equiv C$ group \\
\hline
\end{tabular}

Scanning Electron Microscopy (SEM)

The micrograph of Maize cob revealed a smooth surface with irregular pores. which could likely provide favoured adsorption site. After dye adsorption, a significant change is observed in the structure of the adsorbents, which appeared to have a rough surface and pores containing new shiny particles after adsorption (Figure1 a-c)

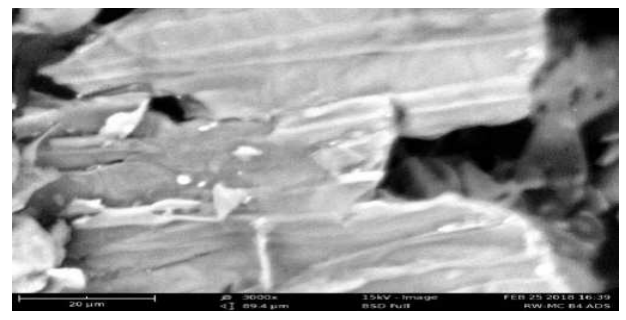

Fig 1a: SEM image of raw maize cob before adsorption

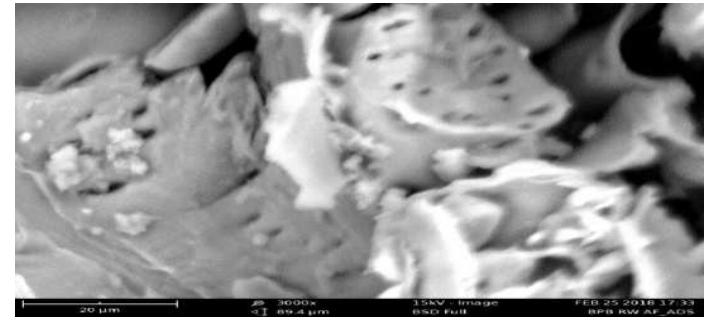

Fig 1b: SEM image of raw maize cob after adsorption of BPB 


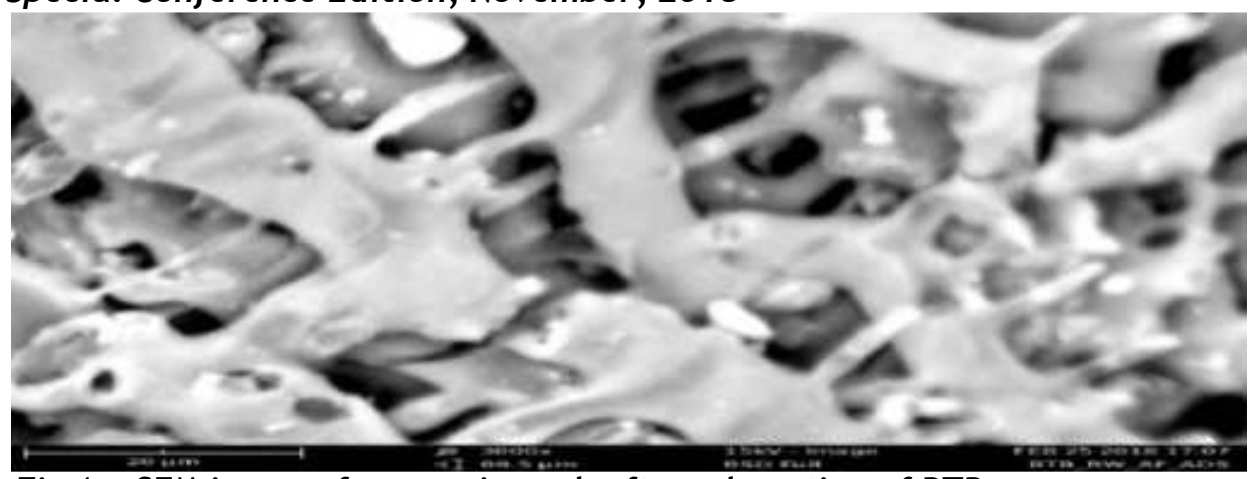

Fig 1c: SEM image of raw maize cob after adsorption of BTB

$\mathrm{pH}$ at Point of zero Charge $\left(\mathrm{pH}_{\mathrm{PzC}}\right)$

The value obtained at the intersection of the initial $\mathrm{pH}$ (pHo, $\mathrm{x}$-axis) with the $\mathrm{pH}=0$ line $(\mathrm{y}$ axis) in Figure 2 gives the $\mathrm{pH}_{\mathrm{pzc}}$ of the raw maize cob at 5.02. This relatively low $\mathrm{pH}_{\mathrm{pzc}}$ value according to Cardenas-Peña et al.(2012). signals the predominance of positively-charged surface groups on the surface of the adsorbent.

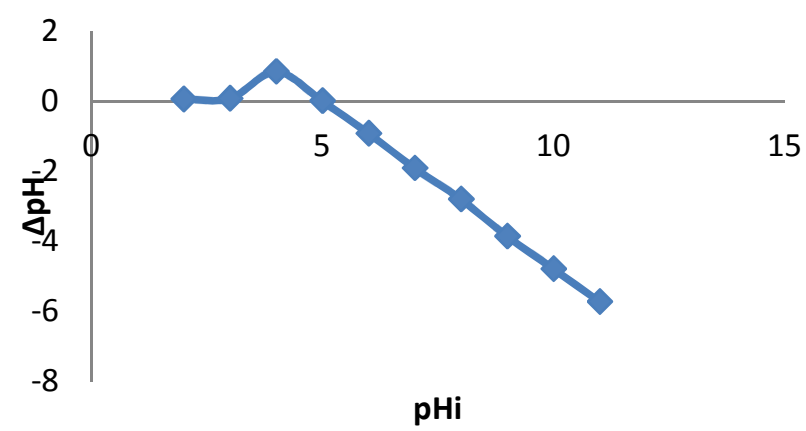

Figure 2: Point of Zero charge of raw maize cob

\section{Effect of contact time}

The effect of contact time on the adsorption of BPB and BTB was examined by varying the time from 5 to 135 minutes as shown in Figure 3. From the figure it can be seen that maximum percentage removal of BPB, and BTB was 28.22 $\%$, and $43.75 \%$ respectively with $10.0 \mathrm{mg} / \mathrm{L}$ initial dye concentration at room temperature $\left(29^{\circ} \mathrm{C}\right)$ using $0.5 \mathrm{~g}$ adsorbent which occurred within the first 125 , and 110 minutes respectively. Similar observation was reported by Adebayo et al. (2015) with raw maize cob for the removal of $\mathrm{Mn}(\mathrm{II})$ and $\mathrm{Co}(\mathrm{II})$ and observed that maximum adsorption were obtained at $120 \mathrm{~min}$.

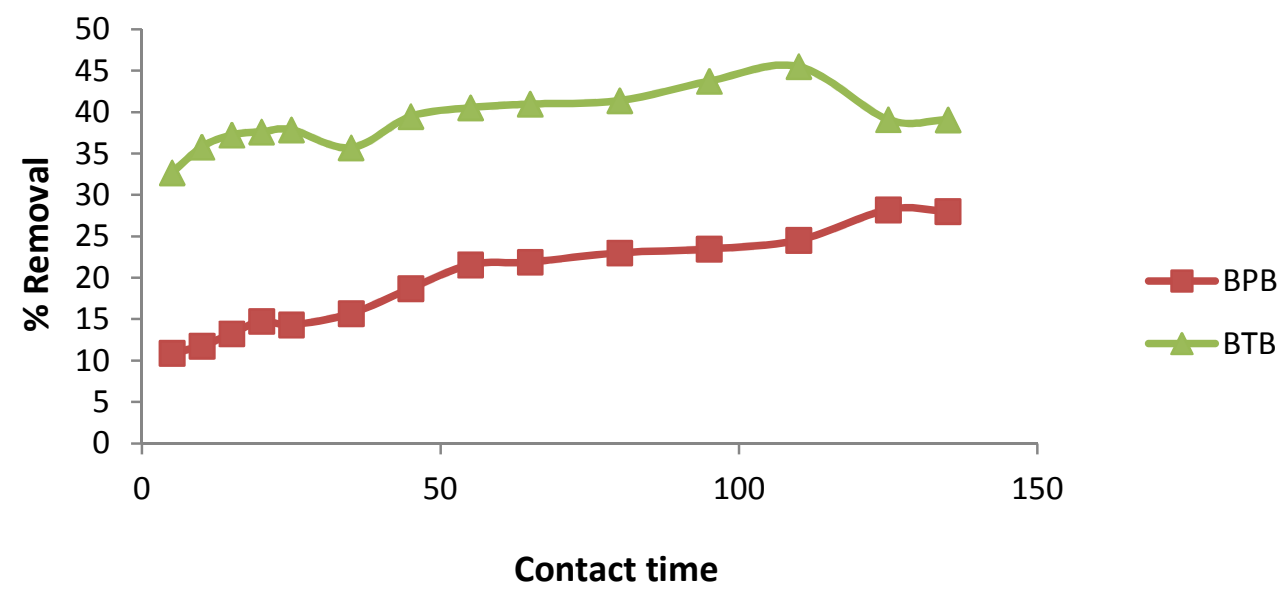

Figure 3: Effect of contact time on the removal of BPB \&BTB with raw maize cob 
Effect of adsorbent Dosage

One of the parameters that strongly affect the sorption capacity is the adsorbent dose. In this work the amount of raw maize cob was varied from 0.5 to $4.0 \mathrm{~g}$ (fig 4) in order to test the effect of adsorbent dosage on the adsorption of these dyes with other parameters kept constant. BPB dye adsorption increases with increase in the dosage from $0.5 \mathrm{~g}$ to $4.0 \mathrm{~g}$ from $21.11 \%$ to $64.68 \%$, which may be attributed to the fact the number of available adsorption sites increases by increasing the adsorbent dose (Charles and Odoemelam 2010; Chamargore et al., 2010; Balasubramani and Sivarajaseka 2014; Patil et al., 2011; Jimoh and Ibrahim
2017; Dim, 2013). While for BTB increase in the dosage from $0.5 \mathrm{~g}$ to $4.0 \mathrm{~g}$ leads to decrease in the removal efficiency of the dye from $53.69 \%$ to $13.79 \%$.

This may be due to the fact that increase in the dosage leads to the formation of aggregates which reduces the surface area on the adsorption site as similarly observed by Tahir et al. (2016) and Vijyakumar et al. (2012). or may be due to increase in unsaturation of adsorption sites or particle interaction, such as aggregation which results as sorbent concentration increases, thereby leading to decrease in total surface area of the adsorbent (Ibrahim and Jimoh, 2008).

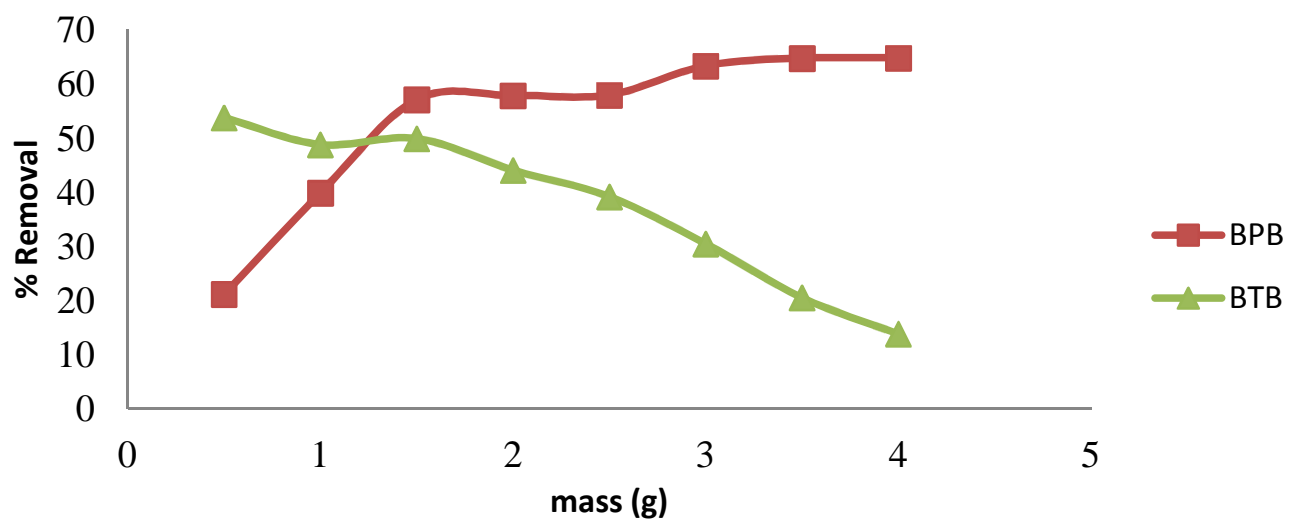

Figure 4: Effect of dosage on removal of BPB \& BTB with Raw maize cob

\section{Effects of Initial Dye Concentration}

The adsorption of dyes by an adsorbents is strongly dependent on the initial concentration of adsorbate molecules in solution. It can be seen that as initial concentration of these dyes were increased from $10 \mathrm{mg} / \mathrm{L}$ to $100 \mathrm{mg} / \mathrm{L}$, corresponding increase in the adsorption capacities also occurred. This can be due to the increasing driving force, to overcome the mass transfer resistance, between the aqueous and solid phase that occurs by increasing the initial concentration of the adsorbates (Taha et al., 2013; Thitame and Shukla 2016; Sartape et al., 2013; Alhaji and Begum, 2015). Moreover, the number of collisions between dye molecules and adsorbent increases, thereby increasing the adsorption (El-Dars et al., 2015).

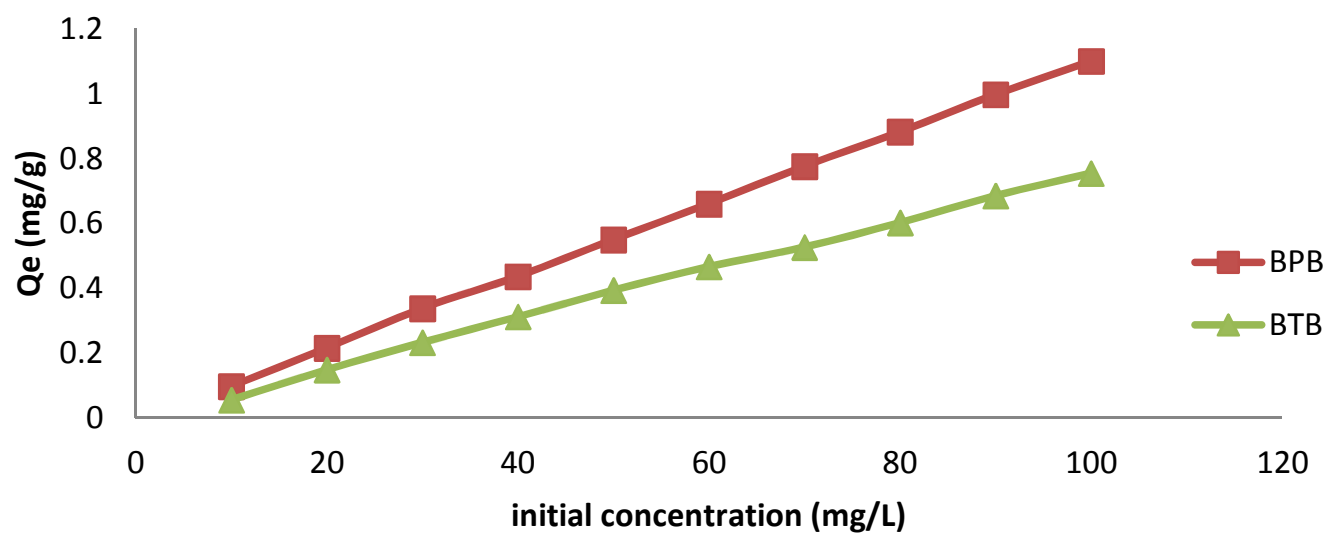

Figure 5: Effect of concentration on removal of BPB \& BTB with raw maize cob 


\section{Effects of Temperature}

The effect of temperature was studied by using the temperatures $298 \mathrm{~K}, 303 \mathrm{~K}, 308 \mathrm{~K}, 313 \mathrm{~K}$ and $318 \mathrm{~K}$. The other parameters were all kept constant at their equilibrium time. Figure 6 shows the effect of solution temperature on the dyes uptake at $100 \mathrm{mg} / \mathrm{L}$ initial concentration. It shows that for BTB percentage removal was slightly increased with increase in temperature from 63.92 to $68.42 \%$, which is due to the increased diffusion of dye molecule across the external and internal boundary layer of the adsorbent due to decrease in solution viscosity. In addition, at higher temperature more dye molecules have sufficient energy to undergo an interaction with active sites of the adsorbent and enhance the dye mobility to penetrate inside the adsorbent's pores (Ahmad et al., 2014). While for BPB the adsorption performance increases with increase in temperature to an optimum value of $89.4 \%$ at $308 \mathrm{~K}$ after which it decreased.

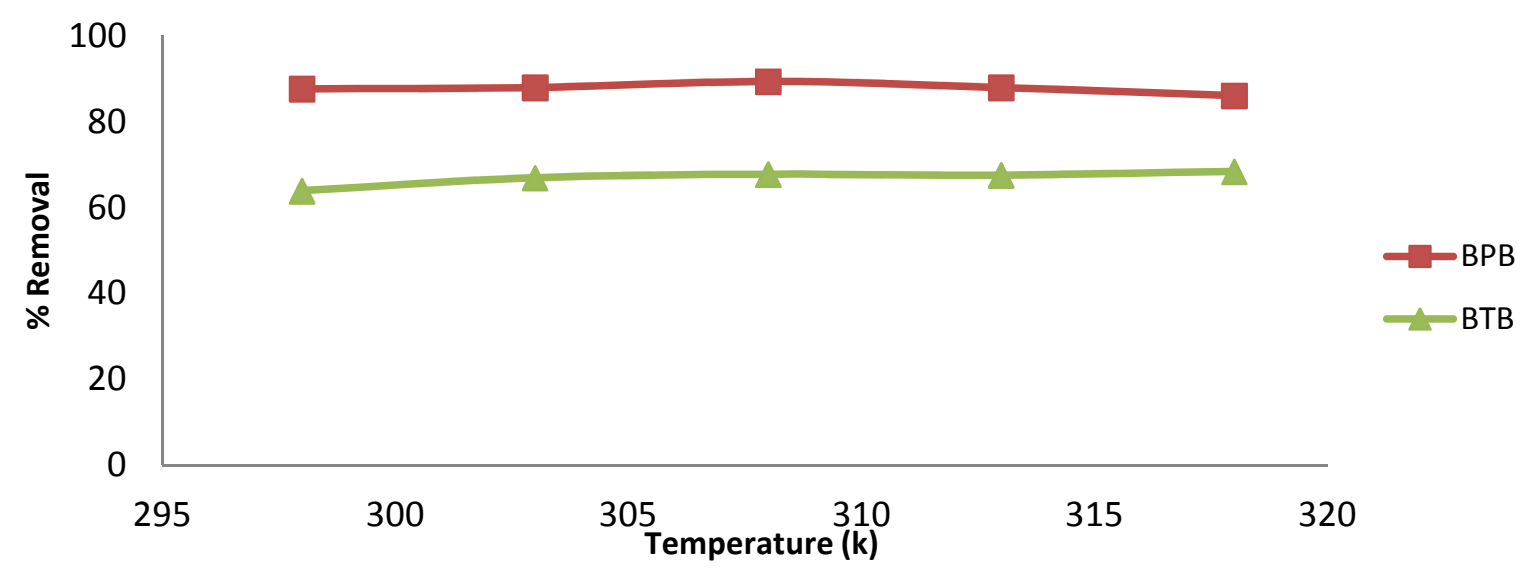

Figure 6: Effect of temperature on removal of BPB \& BTB with raw maize cob

\section{Effect of $\mathrm{pH}$}

In this work the $\mathrm{pH}$ of the dyes was varied from 2 to 12 (Figure 7) as the other parameters were kept constant. At lower $\mathrm{pH}$, increased percentage removal was observed which decreased at higher $\mathrm{pH}$. This behavior can theoretically be explained by the point of zero charge of the adsorbent, at $\mathrm{pH}<$ isoelectrical point, the surface gets positively charged, which enhances the adsorption of the negatively charged adsorbates through electrostatic forces of attraction. At $\mathrm{pH}>$ isoelectrical point, the surface of adsorbent particles gets negatively charged, which favours the adsorption of cationic adsorbates (Santhi et al., 2011; Vijayakumar et al., 2012). This result also is in agreement with the result obtained by Ishaq et al. (2014) and Tchuifon et al. (2014).

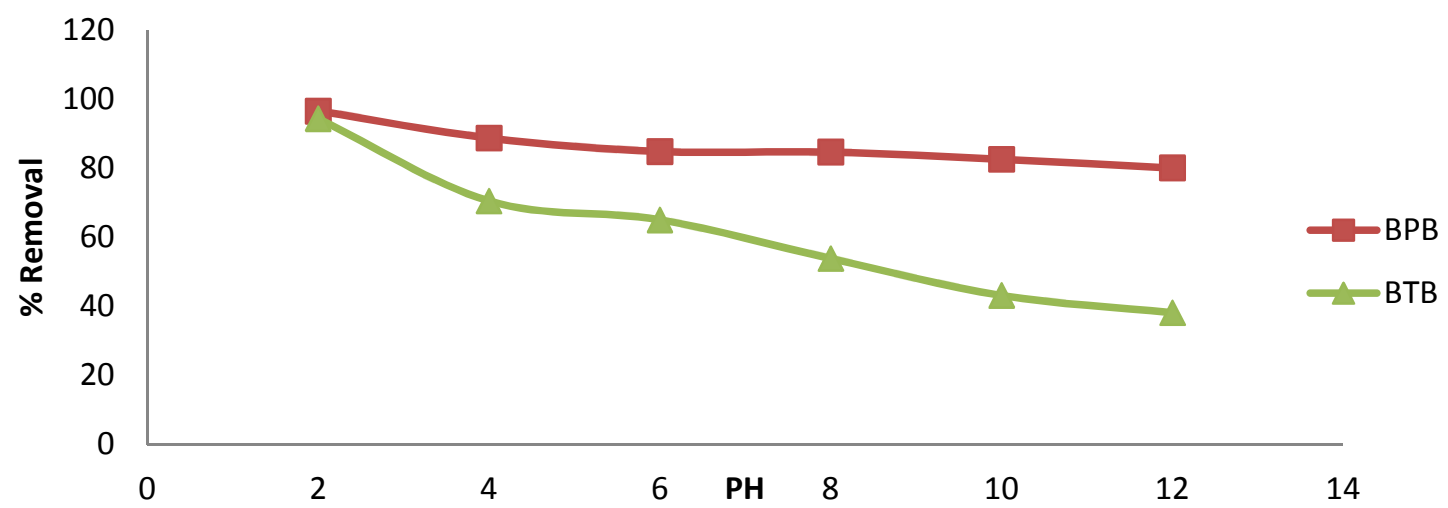

Figure 7: Effect of $\mathrm{pH}$ on removal of BPB \& BTB with raw maize cob

\section{Adsorption Kinetics}

Values of Kinetics parameters as deduce from various kinetic plots are as presented in table 2. From the table, the $\mathrm{q}_{\mathrm{e}}$ experimental and the $\mathrm{q}_{\mathrm{e}}$ calculated values for all the dyes are very close to each other. The calculated correlation coefficients $\left(R^{2}\right)$ are also close to unity. Therefore, the adsorption can be approximated more appropriately by pseudo second order kinetic model. Also from the table value of 
Special Conference Edition, November, 2018 $\alpha>\beta$ from Elovich equation for BTB indicates adsorption to predominates desorption process and vice versa. While from intraparticle diffusion $\alpha$-values less than 0.50 indicates that intraparticle diffusion is not a rate determining step during the adsorption process (Ramesh et al., 2013).

Table 2: Adsorption Kinetic Parameters for adsorption of BPB and BTB onto Raw maize cob

\begin{tabular}{|c|c|c|c|}
\hline \multirow[b]{2}{*}{ Model } & \multirow[b]{2}{*}{$\begin{array}{l}\text { Kinetic } \\
\text { Parameters }\end{array}$} & \multicolumn{2}{|c|}{ Raw Maize Cob } \\
\hline & & BPB & BTB \\
\hline & $q_{e, \exp .}(m g / g)$ & 0.318 & 0.546 \\
\hline Pseudo First Order & $\mathrm{q}_{\mathrm{e}, \text { cal. }}(\mathrm{mg} / \mathrm{g})$ & 0.112 & 0.004 \\
\hline $\ln \left(q_{e}-q_{t}\right)=\ln q_{e}-k_{1} t$ & $\begin{array}{l}\mathrm{k}_{1}\left(\min ^{-1}\right) \\
\mathrm{R}^{2}\end{array}$ & $\begin{array}{l}0.001 \\
0.003\end{array}$ & $\begin{array}{l}0.000 \\
0.000\end{array}$ \\
\hline Pseudo Second Order & $\mathrm{q}_{\mathrm{e}, \text { cal. }}(\mathrm{mg} / \mathrm{g})$ & 0.325 & 0.516 \\
\hline$\frac{t}{a_{0}}=\frac{1}{K_{0} a^{2}}+\frac{1}{a} t$ & $\mathrm{k}_{2}(\mathrm{~g} / \mathrm{mg} \cdot \min )$ & 0.212 & 0.694 \\
\hline Elovich & $\begin{array}{l}\mathrm{R}^{2} \\
\mathrm{a}(\mathrm{mg} / \mathrm{g} \cdot \mathrm{min})\end{array}$ & $\begin{array}{l}0.981 \\
0.131\end{array}$ & $\begin{array}{l}0.989 \\
430.38\end{array}$ \\
\hline $\mathrm{q}_{\mathrm{t}}=\frac{1}{B} \ln (\mathrm{a} B)+\frac{1}{B} \ln (\mathrm{t})$ & $\begin{array}{l}B(g / m g) \\
R^{2}\end{array}$ & $\begin{array}{l}20.408 \\
0.911\end{array}$ & $\begin{array}{l}27.78 \\
0.733\end{array}$ \\
\hline Intraparticle Diffusion & $\alpha(\mathrm{mg} / \mathrm{g})$ & 0.304 & 0.078 \\
\hline $\log \mathrm{R}=\log \mathrm{K}_{\mathrm{id}}+\alpha \log (\mathrm{t})$ & $\begin{array}{l}\mathrm{k}_{\text {diff }}\left(\min ^{-1}\right) \\
\mathrm{R}^{2}\end{array}$ & $\begin{array}{l}5.957 \\
0.955\end{array}$ & $\begin{array}{l}29.309 \\
0.752\end{array}$ \\
\hline
\end{tabular}

\section{Adsorption Isotherms}

Adsorption isotherm describes how adsorbates interact with adsorbents and therefore it is critical in optimizing the use of adsorbents (Hadi et al., 2010; Boumchita et al., 2016). Results from Table 3 indicated that the adsorption of the dyes onto the adsorbent surface showed a physical sorption character since the Temkin isotherm constant $b$ was found to be lower than $8 \mathrm{~kJ} / \mathrm{mol}$. In addition, high linear regression value indicates that adsorption process fits closely with Temkin isotherm model. Also from the Table, the $\mathrm{E}$ from $D-R$ isotherm values for the adsorption of the dyes are in the range of $0-2 \mathrm{~kJ} / \mathrm{mol}$. Therefore, the adsorption process by the adsorbent indicated physical process (Akalin et al., 2017).

Table 3: Langmuir, Freundlich, Temkin and D-R isotherm parameters for the adsorption of BPB and BTB onto Raw maize cob

\begin{tabular}{|c|c|c|c|}
\hline \multirow[b]{2}{*}{ Adsorption isotherm } & \multirow[b]{2}{*}{ Parameters } & \multicolumn{2}{|c|}{ Raw Maize Cob } \\
\hline & & BPB & BTB \\
\hline \multirow{4}{*}{$\begin{array}{l}\text { Langmuir } \\
\frac{\mathrm{Ce}}{\mathrm{qe}}=\frac{1}{\mathrm{Kl} \mathrm{Qm}}+\frac{C e}{Q m} \\
\mathrm{R}_{\mathrm{L}}=\frac{1}{1+K l C o}\end{array}$} & $\mathrm{Q}_{M}(\mathrm{mg} / \mathrm{g})$ & -1.822 & -14.706 \\
\hline & $\mathrm{R}_{\mathrm{L}}$ & -0.397 & 5.258 \\
\hline & $\mathrm{K}_{\mathrm{L}}(\mathrm{L} / \mathrm{mg})$ & -0.035 & 0.008 \\
\hline & & 0.228 & 0.178 \\
\hline \multirow{3}{*}{$\begin{array}{l}\text { Freundlich } \\
\log q_{e}=\log K_{f}+\frac{1}{n_{f}} \log C_{e}\end{array}$} & $\mathrm{n}_{\mathrm{F}}$ & 0.809 & 0.841 \\
\hline & $\mathrm{K}_{\mathrm{F}}(\mathrm{mg} / \mathrm{g})$ & 0.057 & 0.086 \\
\hline & $\mathrm{R}^{2}$ & 0.924 & 0.953 \\
\hline Temkin & $\mathrm{K}_{\mathrm{T}}(\mathrm{L} / \mathrm{mg})$ & 0.521 & 0.185 \\
\hline \multirow{3}{*}{$\begin{array}{c}\mathrm{q}_{\mathrm{e}}=\mathrm{B}_{\mathrm{T}} \ln \mathrm{K}_{\mathrm{T}}+\mathrm{B}_{\mathrm{T}} \ln \mathrm{C}_{\mathrm{e}} \\
\mathrm{B}_{\mathrm{T}}=\frac{R T}{b_{T}}\end{array}$} & $\mathrm{~b}_{\mathrm{T}}(\mathrm{kJ} / \mathrm{mol})$ & 4.532 & 0.910 \\
\hline & $\mathrm{B}_{\mathrm{T}}(\mathrm{J} / \mathrm{mol})$ & 0.554 & 2.759 \\
\hline & $\mathrm{R}^{2}$ & 0.957 & 0.971 \\
\hline$D-R$ & $\mathrm{Q}_{n}(\mathrm{mg} / \mathrm{g})$ & 1.042 & 4.656 \\
\hline $\log q_{e}=\log q_{m}-B \varepsilon^{2}$ & $\mathrm{~B}\left(\mathrm{~mol}^{2} / \mathrm{kJ}^{2}\right)$ & 1.086 & 6.226 \\
\hline$\varepsilon=\mathrm{RT} \ln (1+1 / \mathrm{Ce})$ & $\mathrm{E}(\mathrm{kJ} / \mathrm{mol})$ & 0.679 & 0.283 \\
\hline $\mathrm{E}=\frac{1}{\sqrt{2 \beta}}$ & $\mathrm{R}^{2}$ & 0.944 & 0.936 \\
\hline
\end{tabular}




\section{Adsorption thermodynamics}

Thermodynamic parameters are essential for the interpretation of the nature and characteristics of adsorption process concerning their physicochemical attributes. Gibbs free energy, adsorption enthalpy, and entropy hold fundamental knowledge about the character of sorption. Gibbs free energy change $(\Delta G)$, provides the information of whether the sorption process is spontaneous or not, Adsorption free enthalpy $(\Delta \mathrm{H})$ change gives the knowledge of the thermal character of the sorption, providing whether the sorption of

$$
\begin{gathered}
\Delta G=\Delta H-T \Delta S \\
\Delta G=-R T \ln K c \\
\mathrm{~K}_{\mathrm{C}}=\frac{\mathrm{Qe}}{\mathrm{Ce}} \\
\ln _{\mathrm{C}}=\frac{\Delta \mathrm{S}}{\mathrm{R}}-\frac{\Delta \mathrm{H}}{\mathrm{RT}}
\end{gathered}
$$

Result demonstrated that dyes adsorption process onto maize cob occurred spontaneously, since $\Delta G$ values were all negative. The negative $\Delta H$ value for BPB indicated that adsorption process had exothermic character, meaning as the temperature increased, the amount of metal ions on adsorbent is endothermic or exothermic and finally, adsorption free entropy change $(\Delta S)$ is an indicator of magnitude concerning the disorder among the adsorbate molecules and adsorbent. Equilibrium constant (Kc) indicate the ability of an adsorbent to hold dye molecule onto its porous structure and amplitude of adsorbate mobility in the adsorption media (Akalin et al., 2017). The general expression of $\Delta G$ is given in Eq. 3 and rearranging $\Delta \mathrm{G}$ as $-\mathrm{RT} \operatorname{lnKC}$ from Eq. 4 gives the Eq. 6 The plot of InKc versus $1 / T$ gives the slope of $\Delta H / R T$ and the intercept of $\Delta S / R$.

adsorbed dye gradually decreased, indicating physisoption. While for BTB its percentage removal increases as the temperature increases indicating endothermic character (chemisorptions) as seen in Table 4 and Positive $\Delta s$ value for BPB, BTB indicated spontaneous process.

Table 4: Thermodynamic parameters for adsorption of BPB and BTB on Raw maize cob

\begin{tabular}{llllll}
\hline & \multicolumn{5}{c}{ Raw Maize Cob } \\
Dyes & Temperature & $\mathrm{K}_{\mathrm{c}}$ & $\Delta \mathrm{G}(\mathrm{kJ} / \mathrm{mol})$ & $\Delta \mathrm{H}(\mathrm{kJ} / \mathrm{mol})$ & $\Delta \mathrm{S}\left(\mathrm{kJmol} \mathbf{K}^{1}\right)$ \\
\hline BPB & 298 & 7.126 & -5.039 & & \\
& 303 & 7.313 & -5.052 & -4.226 & 0.003 \\
& 308 & 8.434 & -5.066 & & \\
& 313 & 7.319 & -5.079 & & \\
& 318 & 6.195 & -5.093 & & \\
BTB & 298 & 1.772 & -1.528 & & \\
& 303 & 2.026 & -1.669 & & \\
& 308 & 2.103 & -1.810 & & \\
& 313 & 2.085 & -1.951 & & \\
& 318 & 2.167 & -2.092 & & \\
\hline
\end{tabular}

\section{CONCLUSION}

The raw maize cob was found to be efficient for removal of the dyes (BPB, and BTB) from aqueous solution, and the adsorption process

\section{REFERENCES}

Abechi, S, E., Gimba, C, E., Uzairu, A., and Dallatu, Y, A. (2013). Preparation and Characterization of Activated Carbon from Palm Kernel Shell by Chemical Activation, Research Journal of Chemical Science, 3(7):54-61.

Adebayo, G. B., Adegoke, H. I., Jamiu, W., Balogun, B. B. and Jimoh, A. A. (2015). Adsorption of $\mathrm{Mn}$ (II) and $\mathrm{Co}(\mathrm{II})$ ions from aqueous solution using maize cob activated carbon: kinetics and thermodynamic studies, J. Appl. Sci. Environ. Manage, 19(4):737-748. was found to fit closely to Pseudo-Second-Order model and the adsorption mechanism can be described by physical means as confirmed from thermodynamic data and isotherm parameters.

Ahmad, M, A., Herawan, S. G., and Yusof, A. A. (2014). Effect Of Activation Time On The Pinang Frond Based Activated Carbon For Remazol Brilliant Blue R Removal, Journal of Mechanical Engineering and Sciences (JMES), Volume 7, pp. 1085-1093.

Akalin, H. A., Hicsonmez, $\mathrm{U}$ and Yilma, $\mathrm{H}$. (2017). Removal of cesium from Aqueous Solution by Adsorption onto Sivasyildizeli (Turkiye) Vermiculite: Equilibrium, Kinetic and Thermodynamic studies, Journal of Turkish General Studies, 5(1):85-116. 
Alhaji, N. M. I and Tajun K. M. (2015). Optimization and kinetic study for the removal of chromium (VI) ions by acid treated sawdust chitosan composite beads. International research journal of pure and applied chemistry. 5(2): 160-176.

Alwan, R. M., Kadhim, Q. A., Sahan, K. M., Ali, R. A., Mahdi, R. J., Kassim, N. A., and Jassim, A. N. (2015). Synthesis of Zinc Oxide Nanoparticles via Sol - Gel Route and Their Characterization, Nanoscience and Nanotechnology, 5(1):1-6.

Balasubramani, K., and Sivarajasekar, N.(2014). Adsorption Studies of Organic Pollutants onto activated Carbon, International Journal of Innovative Research in Science, Engineering and Technology, 3(3): 2319-8753.

Banerjee, S. and Chattopadhyaya, M. C.(2013).Adsorption Characteristic for the Removal of a Toxic Dye Tatrazine from Aqueous Solutions by a Low Cost Agricultural By-product, Arabian Journal of Chemistry, 1878-5352

Bentahar, S., Dbik, A., El-khomar, M., Elmessaoudi, N., Bakiz, B., and Lacherai, A.(2016). Sturdy of the Removal of Congo Red by Local Natural Clay, Chemistry \& Chemical Engineering, Biotechnology, Food Industry, Scientific Sturdy and Research, 17(3):295-307.

Boumchita, S., Lahrichi, A., Benjelloun, Y., Lairini, S., Nenov, V., Zerrouq, F. (2016). Application of Peanut shell as a low-cost adsorbent for the removal of anionic dye from aqueous solutions, Journal of Materials and Environmental Sciences, 8(7): 2353-2364

Cardenas-Peña, A. M., Ibanez, J. G., VasquezMedrano, R. (2012). Determination of the Point of Zero Charge for Electrocoagulation Precipitates from an Iron Anode, Int J. Electrochem. Sci, 7:6142 - 6153 .

Chamargore, J. J., Bharad, J. V., Madje, B. R. And Ubale, M. B. (2010). The Removal of Dye from Aqueous Solution by Adsorption on Low Cost Adsorbents, $E$ Journal of Chemistry, 7(3): 1003-1007.

Charles, O. I. and Odoemelam, S. A.(2010). Studies on Adsorbent Dosage, Particle Sizes and $\mathrm{pH}$ Constraints on Biosorption of $\mathrm{Pb}(\mathrm{II})$ and $\mathrm{Cd}(\mathrm{II})$ lons from Aqueous Solution Using Modified and Unmodified Crasstrotrea Gasar (Bivalve) Biomass, International Archive of Applied Sciences and Technology, 1(1):62-68.
Dim, P. E. (2013). Adsorption of Methyl Red and Methyl Orange using Different Tree Bark Powder, Academic Research International, 4(1):330-338.

El-Dars, F. M. S., Ibrahim, H. M., Farag, H. A.B., Abdelwahhab, M. Z., and Shalabi , M.E. H.(2015).Adsorption Kinetics of Bromophenol Blue and Eriochrome Black $T$ using Bentonite Carbon Composite Material, International Journal of Scientific \& Engineering Research, 6(5):679-688.

Gayathiri, R., Thirumarimurugan, M., and Kannadasan ,T.(2013). Removal of Chromium (v1) lons from Aqueous Solutions Using Tamarind Seeds as an Adsorbent,Internaional Journal of Pharmaceutical and Chemical Reasearch (IJRPC), 2(2):984-991.

Hadi, M., Samarghandia, M. R., and McKayb, G. (2010). Equilibrium two-parameter isotherms of acid dyes sorption by activated carbons: Study of residual errors, Chemical Engineering Journal,160, 408-416.

Hassan, K. H., and Mahdi, E. M.(2016). Synthesis and Characterization of Copper,Iron Oxide Nanoparticles used to Remove Lead from Aquous Solution, Asian Journal of Applied Sciences, 4(3);730-738.

Ibrahim, M, B. and Jimoh, L, O. (2011). Remedation of $\mathrm{Cr}$ and $\mathrm{Fe}$ from Aqueous Solution by Natural Adsorbents, International Journal of Biological and Chemical Sciences, 5(3):915-922.

Ibrahim, M. B. and Sani, S. (2014.) Comparative Isotherms Studies on Adsorptive Removal of Congo Red from Wastewater by Watermelon Rinds and Neem-Tree Leaves. Open Journal of Physical Chemistry, 4, pp139-146.

Ibrahim, M. B., and Jimoh, W. L. O.(2008). Adsorption Studies for the Removal of $\mathrm{Cr}(\mathrm{VI})$ Ion from aqueous Solution, Bayero Journal of Pure and Applied Sciences, 1(1):99 - 103.

Ibrahim, M. B., Haruna. M. A., and Ibrahim, A. M. (2012). Optimization Of Crystal Violet Dye Removal From Aqueous Solution Using Agro Wastes, ChemSearch Journal, 3(1): $28-33$.

Ishaq, M., Saeed, K., Shoukat, A., Ahmad, I. and Khan, A. R. (2014). Adsorption of Alizarin Red Dye from Aqueous Solution on an Activated Charcoal, International Journal of Science Inventions Today,3(6):705-718. 
Jimoh, A. and Ibrahim, M. B.(2017). Manganese (IV) Oxide Nanoparticles Loaded on Activated Carbon as Adsorbent for Removal of Eriochrome Black $\mathrm{T}$ and Methyl Orange, Yusuf Maitama Sule University, Proceeding of the 3rd Annual International Science Conference, 71-83.

Kandis, R. V., KV, S. N., Shaik, K. B., and Gopinath, R.(2016). Dye Removal by Adsorption: A Review, Journal of Bioremediation Biodegradation, 7(6):1-4.

Karasavvidis, CH., loannou, Z., and Dimirkou, A.(2013). Removal of Methylene Blue from Aqueous Solutions Using Modified Zeolite and ctivated Carbon under SemiBatch and Batch Operations, Proceedings of the 13th International Conference of Environmental Science and Technology Conference, 5-7. Nale, B. Y., Kagbu, J. A., Uzairu A., Nwankwere E. T., Saidu S. and Musa H. (2012). Kinetic Equilibrium Studies of the Adsorption of Lead(II) and Nickel(II) ions from aqueous solutions on Activated Carbon Prepared from Maize Cob, Pelagia Research Library, Der Chemica Sinica, 3(2):302-312.

Omran, A. R., Baiee, M. A., Juda, S. A., Salman, J. M., AlKaim, A. F.(2016) Removal of Congo red dye from aqueous solution using a new adsorbent surface developed from aquatic plant (Phragmites australis), International Journal of ChemTech Research, 9(4): 334-342.

Patil, S., Renukdas, S., and Patel, N. (2011). Removal of methylene blue, a basic dye from aqueous solutions by adsorption using teak tree ( Tectona grandis) bark powder, International Journal of Environmental Sciences, 1(5): 0976 4402.

Ramesh, S. T., Gandhimathi, R., Elavarasi, T. E., Isaithamizh, R., Sowmay, K. and Nidheesh, P.V.(2013). Comparison of methylene blue adsorption from aqueous solution using spent tea dust and raw coir pith Global NEST Journal, xx(x):1-14.

Santhi, T., Manonmani, S., Vasantha, V. S., and Chang, Y. T.(2011).A new alternative adsorbent for the removal of cationic dyes from aqueous solution, Arabian Journal of Chemistry, 9, pp 466-474.

Saritha, B., Rajasekhar, K. and Kiso, K.(2015). Equilibrium Studies of Methylene Blue from Aqueous Solution using Low Cost Adsorbent, International Journal of Innovation Resaerch in Science, Engineering and Technology, 4(8):68216828.

Sartape, A. S., Mandhare, A. M., Jadhav, V. V., Raut, P. D., Anuse, M. A., and Kolekar,
S. S. (2013). Removal of malachite green dye from aqueous solution with adsorption technique using Limonia acidissima (wood apple) shell as low cost adsorbent, Arabian Journal of Chemistry, xxx, pp 1-10.

Sayan, E., Ata, O. N. and Edecan, M. E.(2014). Investigation of Adsorption Thermodynamics on Removal of Reactive Blue 19 onto Activated Carbon under Ultrasonic Irradiation, J.Chem.Soc.Pak, 36(2):232-238.

Suteu, D., Malutan, T. and Bilba, D. (2011). Agricultural Waste Corn Cob as a Sorbent for Removing Reactive Dye Orange 16: Equilibrium Study, Celloluse Chemisry and Technology, 45(5-6) 413420.

Taha, D. N., Samaka, I. S. and Mohammed, L. A.(2013). Adsorptive Removal of Dye from Industrial Effluents using Natural Iraqi Palygorskite Clay as Low-Cost Adsorbent, Journal of Asian Scientific Research, 3(9):945-955.

Tahir, H., Sultan, M., Akhtar, N., Hameed, U. and Abid, T.(2016). Application of natural and modified sugar cane bagasse for the removal of dye from aqueous solution, Journal of Saudi Chemical Society, 20, 115-121.

Tchuifon,, D. R., Anagho, S. G., Njanja, E., Ghogomu, J. N., Ndifor-Angwafor, N. G. and Kamgaing, T. (2014). equilibrium and kinetic modelling of methyl orange adsorption from aqueous solution using rice husk and egussi peeling, Int. J. Chem. Sci,12(3):741-761.

Thitame, P. V. and Shukla, S. R. (2016). Adsorptive removal of reactive dyes from aqueous solution using activated carbon synthesized from waste biomass materials, Int. J. Environ. Sci. Technol. 13:561-570

Vijayakumar, G.,Tamilarasan, R. and Dharmendirakumar, M. (2012). Adsorption, Kinetic, Equilibrium and Thermodynamic studies on the removal of basic dye Rhodamine- $B$ from aqueous solution by the use of natural adsorbent perlite, J. Mater. Environ. Sci, 3 (1):157-170.

Zvzdova, D. and Georgieva, S. (2013). Kinetic and Equilibrium Studies on the Removal of Congo Red from Aqueous Solution by Biosorption on Crosslinked ChitosanЕСН Nanoparticle, НАУЧНИ ТРУДОВЕ НА РУСЕНСКИЯ УНИВЕРСИТЕТ, ТОМ 52 , серия 10.1. 